\title{
Imaging of IPMN of the pancreas: evaluation of malignant potential and resectability
}

\author{
Jeong Min Lee \\ From International Cancer Imaging Society Meeting and 15th Annual Teaching Course (ICIS 2015) \\ London, UK. 5-7 October 2015
}

Intraductal papillary mucinous neoplasm (IPMN) of the pancreas is defined as a tumor growing in the main duct or branch duct of the pancreas, with differentiated papillary features and production of atypical mucin, as well as segmental or diffuse dilation of the main pancreatic duct (MPD), cystic dilation of the secondary branches, or both. Histologically they exhibit a wide spectrum of dysplastic changes from low and moderate grade dysplasia to high grade dysplasia (in situ carcinoma) to eventually, invasive carcinoma. The international consensus guidelines 2012 for the management of IPMNs and mucinous cystic neoplasms of the pancreas have been issued. The new international consensus guidelines recommend multidetector row $\mathrm{CT}$ or $\mathrm{MR}$ imaging with MR cholangiopancreatography $(\mathrm{CP})$ in the evaluation of pancreatic cysts larger than $1 \mathrm{~cm}$ to check for high-risk stigmata or worrisome features. In cysts that show high-risk stigmata, surgical management is recommended. In this lecture, I would like to discuss the diagnostic performance of magnetic resonance imaging (MRI) with MR cholangiopancreatography (MRCP) and diffusion weighted imaging, and MDCT in determining the malignant potential and surgical resectability of pancreas IPMNs using pathologic and surgical analyses as reference standards. In addition, I would like to discuss interobserver agreement of each diagnostic criterion on CT and MRI for evaluation of the malignant potential of IPMNs.

Published: 2 October 2015

\section{References}

1. Kim SH, Lee JM, Lee ES, Baek JH, Kim JH, Han JK, Choi BI: Intraductal papillary mucinous neoplasms of the pancreas: evaluation of malignant

Correspondence: jmlshy2000@gmail.com

Department of Radiology, Seoul National University Hospital, Seoul 110-744, South Korea original work is properly cited. The Creative Commons Public Domain Dedication waiver (http://creativecommons.org/publicdomain/ zero/1.0/) applies to the data made available in this article, unless otherwise stated. potential and surgical resectability by using MR imaging with MR cholangiography. Radiology 2015, 274(3):723-33.

2. Tanaka M, Fernandez-del Castillo C, Adsay V, et al: International consensus guidelines 2012 for the management of IPMN and MCN of the pancreas. Pancreatology 2012, 12(3):183-197.

3. Manfredi R, Graziani R, Motton M, et al: Main pancreatic duct intraductal papillary mucinous neoplasms: accuracy of MR imaging in differentiation between benign and malignant tumors compared with histopathologic analysis. Radiology 2009, 253(1):106-115.

4. Vullierme MP, Giraud-Cohen M, Hammel P, et al: Malignant intraductal papillary mucinous neoplasm of the pancreas: in situ versus invasive carcinoma surgical resectability. Radiology 2007, 245(2):483-490.

doi:10.1186/1470-7330-15-S1-06

Cite this article as: Lee: Imaging of IPMN of the pancreas: evaluation of malignant potential and resectability. Cancer Imaging 2015 15(Suppl 1): O6.

Submit your next manuscript to BioMed Central and take full advantage of:

- Convenient online submission

- Thorough peer review

- No space constraints or color figure charges

- Immediate publication on acceptance

- Inclusion in PubMed, CAS, Scopus and Google Scholar

- Research which is freely available for redistribution 